\title{
Internalisasi Nilai-Nilai Spiritual Islam di SMK Plus Multazam
}

\author{
Nurjamal \\ Institut Agama Islam Darussalam (IAID) Ciamis, Jawa Barat. \\ Email: nurjamal1994@gmail.com \\ Didih Syakir Munandar \\ Institut Agama Islam Darussalam (IAID) Ciamis, Jawa Barat. \\ Email: didih.smiaid@gmail.com
}

Received: July 8, 2018 | Accepted: April 7, 2019

\begin{abstract}
This study aims to determine the concept of internalization, internalization strategies and factors supporting and inhibiting the internalization of Islamic spiritual values in SMK Plus Multazam. This study uses a qualitative descriptive method. The object in this study is the SMK Plus Multazam. Data collection techniques use interview, observation, and study documentation. The results showed that the concept of internalizing Islamic spiritual values in SMK Plus Multazam was through the stage of value transformation, transaction value and the stage of transinternalization. Then, the strategy of internalizing Islamic spiritual values in SMK Plus Multazam was carried out through planning contained in the school curriculum, local content subjects, extra-curricular, school education calendars and school rules. The implementation is through the strategy of habituation, punishment, exemplary, advice, and student awareness. Supporting factors in forming students' Islamic spiritual values include daily worship, monthly worship and insidental worship as well as direct monitoring from the school and inhibiting factors including wrong association, families who are less supportive, lack of student awareness and the student's living environment.
\end{abstract}

\begin{abstract}
Abstrak
Penelitian ini bertujuan untuk mengetahui konsep internalisasi, strategi internalisasi serta faktor pendukung dan penghambat internalisasi nilai-nilai spiritual Islam di SMK Plus Multazam. Penelitian ini menggunakan metode deskriptip kualitatif. Objek dalam penelitian ini adalah sekolah SMK Plus Multazam. Tehnik pengumpulan data menggunakan wawancara, observasi, dan studi dokumentasi. Hasil penelitian menunjukkan bahwa konsep internalisasi nilai-nilai spiritual Islam di SMK Plus Multazam yaitu melalui tahap transformasi nilai, transaksi nilai dan tahap terinternalisasi. Kemudian, strategi internalisasi nilai-nilai spiritual Islam di SMK Plus Multazam dilaksanakan melalui perencanaan yang tertuang dalam kurikulum sekolah, mata pelajaran muatan lokal, ekstra kurikuler, kalender pendidikan sekolah serta tata tertib sekolah. Strategi internalisasi ini diorganisir oleh pembina yayasan dan segenap pendidik yang ada di sekolah. Adapun pelaksanaannya melalui strategi pembiasaan, hukuman,
\end{abstract}


keteladanan, nasihat, serta kesadaran siswa. Faktor pendukung dalam membentuk nilai spritual Islam siswa diantaranya melalui ibadah harian, ibadah bulanan dan ibadah insidental serta adanya pemantauan langsung dari pihak sekolah dan faktor penghambat diantaranya pergaulan yang salah, keluarga yang kurang mendukung, kurangnya kesadaran siswa dan lingkungan tempat tinggal siswa.

\section{Keywords}

Islamic education, internalization, values, Islamic spiritual

\section{Pendahuluan}

Nilai-nilai Islam pada hakikatnya adalah kumpulan dari prinsip-prinsip hidup, ajaran-ajaran tentang bagaimana manusia menjalankan kehidupannya di dunia. Tidak ada satupun nilai yang dapat berdiri sendiri, satu prinsip dengan prinsip lainnya saling keterkaitan membentuk satu kesatuan yang utuh. Satu nilai dengan nilai lainnya membentuk sesuatu yang disebut dengan sistem nilai yang kokoh dan menyatu, yakni sistem Islam (Frimayanti, 2017, p. 232).

Pengamalan sistem Islam dalam bentuk ajaran-ajaran Islam pada kehidupan manusia adalah untuk kepentingan dirinya sendiri, bukan untuk kepentingan Allah. Manusialah yang berhajat dan butuh kepada Allah Swt. Oleh sebab itu Islam membimbing manusia menurut kebutuhannya. Islam adalah agama yang menjadi sumber pendidikan kemanusiaan. Islam mendidik manusia berkarakter dan berakhlak yang sumbernya dari tauhid. Sebagaimana tauhid itulah yang membina manusia beribadah kepada Allah Swt, sebagai kewajiban hidupnya (Nursyamsu, 2017, p. 145). Menurut Nurul Zuriah, nilai pendidikan agama islam yang harus ditanamkan pada jenjang menengah atas adalah nilai religiusitas, sosialitas, gender, keadilan demokrasi, kejujuran, kemandirian, daya juang, tanggung jawab dan penghargaan terhadap lingkungan alam (Zuriah, 2011, p. 56).

Sejauh ini penanaman nilai-nilai keagamaan di sekolah masih menitikberatkan kepada domain kognitif yang cenderung menampilkan agama sebagai rumusan indoktrinatif-normatif. Hal ini terbukti bahwa pembelajaran hanya berfokus pada penyampaian materi semata atau pengetahuan (transfer of knowledge) penyampaian ketrampilan (transfer of skills) tanpa disertai dengan keteladanan dan pembiasaan moral dan etika (transfer of value). Padahal upaya penanaman nilai keagamaan tidak sekedar menyangkut dimensi kepercayaan tetapi lebih dari itu yaitu pembudayaan dan pembiasaan dalam kehidupan sehari-hari (Azizy, 2003, p. 19). 
Usia remaja merupakan usia yang sulit, terutama karena usia itu merupakan tahap kehidupan saat banyak orang mulai menyadari kenyataan bahwa hidup ini sulit. Remaja yang bijaksana menyadari bahwa sisa hidup mereka akan sangat membutuhkan perjuangan, kerja keras secara fisik, emosional, dan spiritual agar dapat bertahan hidup. Banyak juga remaja yang mengambil jalan yang salah, seperti penyalahgunaan narkoba, minuman keras, ganja, seks, pelanggaran hukum, dan sebagainya. Terkadang mereka memanfaatkan orang lain hanya demi kepuasan pribadi (Nurhasanah \& Supriyanto, 2012, p. 48)

Akhir -akhir ini banyak terjadi tawuran antar pelajar sebagai contoh; dua kelompok pelajar terlibat tawuran di jalan raya puspitek Kecamatan Setu, Tangerang Selatan, Banten, Selasa (31/7/2018). Akibatnya, seorang pelajar kondisinya kritis setelah menerima sabetan senjata tajam saat tawuran pecah. Informasi yang dihimpun, para pelajar dari SMK Bhipuri Serpong dengan SMK Sasmita Jaya Pamulang ini, mempersenjatai diri mereka dengan berbagai jenis senjata tajam seperti celurit, golok, parang, kayu balok, dan jenis senjata lainya. Dalam keributan antar dua pelajar sekolah menengah atas itu, sedikitnya melibatkan puluhan pelajar dari masing-masing sekolah dan menelan satu orang siswa kelas dua belas yang tertancab cerulit di kepalanya. Dari perisitwa di atas, kondisi remaja khususnya anak sekolah menengah atas sangatlah memperihatinkan (Noviandi, 2018).

Sekolah merupakan salah satu lembaga pendidikan yang bersifat formal, dimana dalam tempat tersebut diadakan kegiatan pendidikan secara teratur, sistematis, mempunyai tanggung jawab dalam kurun waktu tertentu. Mulai dari pendidikan dasar sampai pendidikan tinggi (perguruan tinggi), yang dilaksanakan berdasarkan aturan resmi yang telah ditetapkan oleh pemerintah.

Sekolah Menengah Kejuruan atau yang disingkat SMK, pada umumnya menganut sistem pembelajaran yang lebih menekanankan kepada keahlian praktis, semisal keahlian dalam bidang mesin, menjahit, tata boga, komputer, dan lainnya. Di sisi lain, pembelajaran nilai spiritual Islam, seolah terpinggirkan dan kalaupun ada, alokasi waktu yang tersedia sangatlah terbatas. Hal ini tentunya berimbas kepada pemahaman siswa yang tidak memaknai nilai-nilai agama sebagai suatu yang penting dan mendasar dalam kehidupan sehari-hari. Oleh karena itu, tidak heran kalau banyak terjadi tawuran antar siswa yang menyebabkan banyak korban, bahkan ada yang sampai meninggal dunia.

SMK Plus Multazam Kecamatan Panawangan Kabupaten Ciamis merupakan salah satu lembaga pendidikan kejuruan yang bersifat formal di bawah naungan Kementrian Pendidikan dan Kebudayaan. Di sekolah inilah penulis melihat hal menarik yang jarang dilakukan oleh sekolah menengah 
kejuruan pada umumnya, yakni proses penanaman nilai-nilai spiritual Islam yang dilakukan sehari-hari dan dilaksanakan secara rutin, terarah, dan sistematis.

Hal ini dapat dibuktikan dengan beberapa proses pembelajaran Islam yang dilakukan di SMK Plus Multazam Kecamatan Panawangan Kabupaten Ciamis. Kegiatan tersebut meliputi shalat dhuha berjama'ah, shalat dzuhur berjama'ah dilanjutkan dengan membaca surat al-waqi'ah, pembacaan shalawat dan tadarus Alquran bersama sebelum proses kegiatan belajar mengajar (KBM) dimulai. Pembelajaran tahfidz Alquran dan bahasa arab sebagai mata pelajaran muatan lokal, mengadakan dzikir bersama setiap bulan sekali, ekstra kurikuler muhadharah, peringatan hari besar Islam (PHBI), dan pengelolaan serta pembagian hewan kurban yang rutin setiap tahun.

Kegiatan-kegiatan tersebut merupakan upaya yang dilakukan pihak sekolah untuk mendidik peserta didiknya agar memiliki nilai lebih dibanding siswa SMK lainnya, yang mana diketahui bahwa tidak sedikit SMK di kabupaten Ciamis atau daerah lainnya belum atau mungkin tidak menerapkan hal seperti itu. Selain itu, juga sebagai upaya agar kelak para alumnus minimal bisa mengamalkan ilmu agama mereka untuk diri mereka sendiri di samping keahlian praktis dan teknis yang selama ini diajarkan.

Internalisasi berasal dari kata internal yang berarti menyangkut bagian dalam. Secara etimologi, internalisasi menunjukkan suatu proses. Dalam kaidah bahasa Indonesia akhiran-isasi mempunyai definisi proses. Sehingga internalisasi dapat didefinisikan sebagai suatu proses. Internalisasi adalah suatu proses yang menjadikan kenyataan sosial yang sudah menjadi kenyataan obyektif itu ditanamkan ke dalam kesadaran (Waluya, 2007: 43).

Dalam proses internalisasi yang dikaitkan dengan pembinaan peserta didik atau anak asuh ada tiga tahap yang mewakili proses atau tahap terjadinya internalisasi yaitu; pertama, tahap transformasi nilai, yaitu suatu proses yang dilakukan oleh pendidik dalam menginformasikan nilai-nilai yang baik dan kurang baik. Pada tahap ini hanya terjadi komunikasi verbal antara pendidik dan peserta didik atau anak asuh; kedua, tahap transaksi nilai, yaitu suatu tahap pendidikan nilai dengan jalan melakukan komunikasi dua arah, atau interaksi antara peserta didik dengan pendidik yang bersifat interaksi timbal balik; ketiga, tahap transinternalisasi, yaitu tahap ini jauh lebih mendalam dari tahap transaksi. Pada tahap ini bukan hanya dilakukan dengan komunikasi verbal tapi juga sikap mental dan kpribadian. Jadi pada tahap ini komunikasi kepribadian yang berperan secara aktif (Muhaimin, 1996, p. 153).

Adapun nilai merupakan perwujudan diri (self actualization) di sini adalah perwujudan potensi-potensi diri menjadi nyata. Secara terminologis, nilai diartikan sebagai standar, norma, aturan yang digunakan untuk mengukur 
segala sesuatu, dengan demikian hukum nilai ada bermacam-macam sesuai dengan jenis-jenis nilai tersebut (Latif, 2007, p. 69).

Spiritual berasal dari kata spirit yang berarti jiwa atau sukma atau roh. Spiritual berarti kejiwaan, rohani, batin, mental atau moral (Depdikbud, 2000, p. 857). Spiritual merupakan konsep keseluruhan tentang spirit, berasal dari bahasa latin spiritus, yang berarti napas. Pada saat ini, spiritual lebih merujuk ke energi hidup dan ke sesuatu dalam diri kita yang "bukan fisik" termasuk emosi dan karakter. Ini termasuk kualitas-kualitas vital seperti energi, semangat, keberanian, dan tekad (Buzan, 2003, p. 15).

Nilai-nilai moral dan spiritual yang telah diajarkan Nabi ternyata dapat memberikan perubahan bagi umat manusia khususnya Islam dalam mencapai derajat tertinggi (kehidupan hakiki). Pengalaman-pengalaman spiritual tersebut dapat memberikan posisi kehidupan yang lebih baik dan dapat dirasakan serta dinikmati halayak muslim (Islam). Akhirnya apa yang telah dibawa Nabi itu dijadikan sebagai "sendi" dalam Islam guna mencapai kedekatan diri kepada Allah. Lima sendi itu yang sering kita kenal dengan sebutan "Rukun Islam" dan kelima hal itu tetap berguna selama seseorang ingat bahwa dasar-dasar tersebut merupakan bagian kepercayaan dan bukan hanya suatu ibadah singkat yang diangkat (Jalaluddin, 2004, p. 5).

\section{Metode Penelitian}

Penelitian ini menggunakan pendekatan kualitatif dengan metode deskriptif. Hal ini digunakan untuk meneliti suatu kondisi kelompok yang dimuat dalam bentuk deskripsi, gambaran, atau lukisan secara sistematis, faktual dan akurat terhadap nilai-nilai spiritual Islam yang diinternalisasikan di SMK Plus Multazam.

Secara umum sumber data penelitian kualitatif ialah tindakan dan perkataan manusia dalam suatu latar yang bersifat alamiah. Adapun data-data yang ada kemudian oleh peneliti dibagi menjadi dua sumber yaitu: satu, sumber primer yaitu data-data yang dikumpulkan untuk mengetahui kegiatan internalisasi dari pendidik kepada peserta didik yang di dalamnya terdapat sumber primer yaitu kepala sekolah, wakasek kurikulum, guru pendidikan agama Islam (PAI) serta perwakilan dari siswa; dua, sumber skunder yaitu sumber pendukung yang berupa literatur-literatur yang relevan dan representatif sebagai penunjang bagi penelitian ini, seperti buku, majalah, laporan hasil seminar, jurnal ilmiah, arsip, dokumen dan sumber-sumber lainnya yang ada hubungannya dengan penelitian ini dan diantara penelitian yang relevan serta berkaitan dengan internalisasi nilai-nilai spiritual Islam (Sugiyono, 2009, p. 22). 
Dalam penelitian ini, peneliti adalah sebagai instrumen pengumpul data. Selain itu instrument pendukung penelitian ini adalah pedoman wawancara, pedoman observasi dan pedoman dokumentasi. Aktivitas dalalm analisis data, yaitu: Pertama, pengumpulan data. Kedua, reduksi data. Ketiga, display data. Keempat verifikasi/ menarik kesimpulan.

\section{Hasil Penelitian dan Pembahasan}

Dalam pembahasan ini data yang disajikan oleh peneliti diperoleh dari hasil observasi, dokumentasi serta wawancara dengan kepala sekolah, wakasek kurikulum, guru mata pelajaran PAI, dan siswa.

\section{Konsep Internalisasi Nilia-Nilai Spiritual Islam di SMK Plus Multazam}

Internalisasi merupakan hasil pemahaman seseorang melalui penanaman nilai yang diwujudkan melalui sikap dalam suatu lingkungan tertentu baik dengan pembinaan, bimbingan dan sebagainya. Tehnik pembinaan nilai spiritual Islam yang dilakukan melalui internalisasi adalah pembinaan yang mendalam dan menghayati nilai-nilai religius (agama) yang dipadukan dengan nilai-nilai pendidikan secara utuh yang sasarannya menyatu dalam pribadi siswa, sehingga menjadi suatu karakter atau watak siswa. Begitu juga konsep internalisasi nilai spiritual Islam di SMK Plus Multazam diharapkan pembiasaan dari kegiatan yang dilaksanakan secara husus dapat membentuk sikap spiritual dan aktualisasi pada kehidupan serta menjadi watak atau karakter siswa. Tahap yang kedua adalah tahap transaksi nilai yang memunculkan segi afektif. Selain diberikan pengetahuan sebuah nilai akan tetapi keaktifan menjadi tolak ukur siswa untuk dapat memahami dan menyampaikan pengetahuannya ke yang lain. Pada tahap ketiga atau terakhir, diharapkan siswa sudah dapat mengamalkan secara istiqomah mengenai ilmu yang telah dipelajari dan dipahaminya sehingga menjadi sebuah karakter.

Strategi Internalisasi Nilia-Nilai Spiritual Islam di SMK Plus Multazam

Proses internalisasi nilai-nilai spiritual Islam menjadi penting bagi siswa, karena secara tidak langsung siswa dapat mengamalkannya pada kehidupan sehari-hari. Hal ini tidak terlepas dari upaya sekolah terutama guru sebagai pendidik untuk dapat menginternalisasikan nilai spiritual kepada siswanya. Adapun strategi internalisasi nilai-nilai spiritual di SMK Plus Multazam adalah melalui perencanaan (planning), pelaksanaan (actuating), dan evaluasi (evaluation).

Perencanaan merupakan langkah awal dalam sebuah kegiatan yang akan dilaksanakan supaya dapat terwujud dengan terarah. SMK Plus Multazam dalam menginternalisasikan nilai-nilai spiritual Islam memiliki strategi 
perencanaan yang tertuang dalam kurikulum sekolah. Dari kurikulum yang digunakan ada sedikit perbedaan penerapan dalam strategi penanaman nilai terhadap siswa yang diantaranya dari segi kompetensi yang harus dicapai. Selain pada kurikulum, perencanaan internalisasi nilai spiritual juga dapat dilihat pada mata pelajaran muatan lokal yang dikembangkan, ekstrakurikuler sekolah, kalender pendidikan, jadwal sekolah serta tata tertib sekolah.

Tahap kedua yaitu tahap pelaksanaan proses internalisasi nilai-nilai keislaman. Perencanaan dan pengorganisasian yang baik kurang berarti bila tidak diikuti dengan pelaksanaan kerja. Untuk itu maka dibutuhkan kerja keras, kerja cerdas dan kerjasama. Semua sumber daya manusia yang ada harus dioptimalkan untuk mencapai visi, misi dan program kerja organisasi. Pelaksanaan kerja harus sejalan dengan rencana kerja yang telah disusun. Kecuali memang ada hal-hal khusus sehingga perlu dilakukan penyesuian.

Dalam pelaksanaan internalisasi nilai-nilai spiritual Islam di SMK Plus Multazam digunakan strategi pembiasaan, hukuman, keteladanan, nasihat yang baik, dan pendekatan holistik atau menyeluruh. Internalisasi nilai-nilai spiritual Islam di sekolah diterapkan kepada siswa melalui pembiasaan amaliah. Disamping pengamalan dari materi pelajaran begitupula pengamalan terhadap kegiatan-kegiatan keagamaan yang sudah terprogram di sekolah, tidak terlepas dari bimbingan para pendidik. Adapun penjelasan dari kegiatan rutin keagamaan yang ada dalam program spiritual Islam di SMK Plus Multazam adalah sebagai berikut: Pertama, program shalat sunnah dhuha berjama'ah yaitu program yang dilakukan di lingkungan sekolah sebelum dilakukannya proses belajar mengajar dan di dalamnya diisi dengan kegiatan membaca doadoa serta tadarus al-Quran yang wajib di ikuti oleh seluruh siswa yang beragama muslim. Kegiatan ini dilakukan setiap hari selasa, rabu, dan kamis pagi hari jam 07.00 WIB yang bertempat di mushola. Nilai spiritual yang diterapkan kepada siswa yakni untuk menumbuhkan rasa cinta terhadap rasul, cinta kepada Alquran, tanda keimanan serta manifestasi rasa syukur kepada Allah.

Kedua, program shalat dzuhur berjama'ah, yaitu program shalat berjama'ah ini dilaksanakan pada waktu shalat dzuhur pada istirahat ke dua. Dalam program ini diisi dengan shalat dzuhur berjama'ah dengan sebelumnya ada penyampaia kultum (kuliah tujuh menit) oleh guru atau pembina keagamaan dan pembacaan surah al-Wâqi'ah setelah shalat dzuhur selesai. Dengan kegiatan ini diharapkan dapat menumbuhkan nilai ukhuwah atau persaudaraan, kedisiplinan, persamaan derajat, ketauhidan, dan rasa syukur kepada Allah.

Ketiga, program hadarah dan yasinan, yaitu kegiatan yang bertujuan untuk memupuk rasa empati siswa dalam mendo'akan saudara, kerabat, dan 
keluarga baik yang masih hidup maupun yang telah meninggal dunia sehinnga siswa dapat mempererat persaudaraan walau melalui do'a. Program ini dilaksanakan pada pagi hari jum'at dan pimpin oleh guru PAI atau terkadang oleh siswa yang telah di tunjuk untuk membacakan hadoroh atau do'a bersama serta dilanjutkan ke pembacaan surat yasin bersama. Nilai yang diterapkan dalam kegiatan ini adalah nilai empati, berbagi pada sesama, bertawakal dan bersyukur.

Keempat, program infak shadaqoh, yaitu dengan program sedekah ini diharapkan siswa dan juga guru memiliki rasa simpati, empati, keikhlasan untuk dapat saling berbagi membantu meringankan sesama muslim baik tetangga, ataupun saudara sesama muslim yang membutuhkan. Kegiatan ini dilaksanakan pada pagi hari setelah acara hadoroh dan pembacaan yasin bersama. Wakasek kesiswaan akan berada di depan mushola untuk pengumpulan infak shadaqoh dari siswa yang satu persatu keluar dengan tertib. Infak shadaqoh ini tidak dibatasi jumlahnya hanya seikhlasnya saja begitupun pemungutan infak yang dilakukan kepada para guru.

Kelima, program ekstra kurikuler muhadharah yaitu kegiatan yang merupakan program husus sekolah untuk menumbuh kembangkan bakat dan minat siswa dalam berdakwah atau berpidato di depan umum. Kegiatan ini dilaksanakan seminggu satu kali pada hari jum'at dari pukul 13.00 WIB sampai dengan selesai. Adapun rangkaian acara di dalamnya adalah : (1) acara dibuka oleh MC (master of ceremony) (2) pembacaan ayat suci Alquran dan shalawat nabi (3) penampilan tahfìdz al-Qur'ân serta menyanyikan bersama mars multazam (4) penampilan para orator dengan 4 bahasa yakni bahasa daerah, bahasa Indonesia, bahasa inggri dan bahasa arab yang masing-masing bahasa di sampaikan oleh dua orator. (5) penampilan kreasi siswa tiap kelas (6) evaluasi dan kultum dari Pembina muhadharah g) do'a dan tutup. Nilai yang diterapkan dalam ekstrakurikuler muhadharah ialah amar ma'rûf nahy almunkar, motivasi rajin belajar, memiliki sifat mandiri dan bertanggung jawab.

Keenam, program dzikir bersama, yaitu program dzikir bersama yang dilaksanakan sebulan sekali pada minggu ke dua hari selasa. Adapun rangkaian acaranya adalah sebagai berikut: pada pukul 07.00 WIB, dilaksanakan pembacaan shalawat bersama yang biasa di lantunkan oleh YPI Multazam MYS dengan harapan mendapatkan syafa'at dan tanda cinta kepada baginda Rasulullah Muhammad. Para siswa sangat antusias dan semangat ketika melantunkan shalawat, hal ini menjadikan tanda bahwa mereka memiliki rasa cinta/mahabbah kepada Rasulullah. Setelah semua warga sekolah kumpul sekitar pukul 07.30 WIB, pembina imam membuka dan memberi arahan serta tatacara shalat sunnah yang akan dilaksanakan yakni pelaksanakan shalat sunnah tasbih dengan tatacara sebagai berikut: (a) niat dan takbiratul ihram 
seperti shalat biasa, (b) membaca surat al-fatihah, (c) membaca surah kemudian membaca tasbih sebanyak 15 kali, (d) Ruku' kemudian membaca tasbih sebanyak 10 kali, (e) sujud' kemudian membaca tasbih sebanyak 10 kali, (f) duduk di antara dua sujud kemudian membaca tasbih sebanyak $10 \mathrm{kali}$, (g) sujud kedua kemudian membaca tasbih sebanyak $10 \mathrm{kali}$, (h) sebelum berdiri atau sebelum tasyahud ahir di bacakan terlebih dahulu tasbih sebanyak 10 kali, hingga total membaca tasbih dalam satu raka'at sebanyak 75 kali. Pelaksanaan shalat ini dilakukan dengan cara dua raka'at salam yang disetiap selesai salam diselingi dengan membaca tasbih bersama secukupnya hingga berdiri lagi untuk takbiratul ihram di rakaat berikutnya hingga total 4 raka'at.

Setelah shalat sunnah tasbih dilaksanakan, kemudian dilanjutkan dengan pelaksanaan shalat sunnah hajat. Hal ini dilakukan dengan harapan segala apa yang dihajatkan baik oleh yayasan, kepala sekolah beserta guru-guru, siswa beserta orangtuanya dapat di kabulkan Allah subhaanahu wataa'ala. Shalat sunnah hajat ini dilaksanakan sebanyak empat raka'at dengan dua kali salam, setiap selesai membaca surah al-fatihah dilanjutkan dengan membaca surah alikhlas di raka'at pertama sebanyak 10 kali, pada raka'at kedua 20 kali, pada raka'at ketiga sebanyak 30 kali dan pada raka'at ke empat sebanyak 40 kali setelah itu ruku' sampai salam seperti shalat biasa.

Setelah acara shalat sunnah selesai, dilanjutkan dengan hadarah/menyampaikan do'a bagi yang telah wafat baik dari keluarga yayasan, guru maupun siswa, mendo'akan yang sakit dan berdo'a bagi kemajuan yayasan, sekolah, dan orangtua siswa. Dalam hal ini mengajarkan nilai spiritual supaya kita ingat terhadap kematian, saling mendo'akan antar sesama muslim dan berharap hanya pada Allah subhanahu wata'ala semata.

Acara terakhir yakni inti acara dzikir bersama dengan melantunkan bacaan dzikir yang telah dirangkum oleh Pembina Yayasan Pendidikan Islam Multazam, yakni Dr. KH. Muhammad Yusuf Sya'rani. Dengan dzikir bersama ini, seluruh elemen sekolah yang ada di SMK Plus Multazam diajak untuk mengingat Allah swt. yang kemudian diakhiri dengan do'a bersama yang dipimpin oleh imam. Dari kegiatan dzikir bersama di atas para guru dan staff menjadi pembimbing serta teladan bagi siswa dengan harapan dapat menjadi kebiasaan dalam mengingat Allah, memupuk rasa kebersamaan, syukur, khauf serta roja' walaupun siswa tersebut sudah lulus dari sekolah.

Selain program rutinitas harian dan bulanan, SMK Plus Multazam juga mengadakan acara rutin tahunan dalam pengamalan syi'ar agama Islam di sekolah dalam rangka mendidik spiritual siswa untuk selalu ingat terhadap rangkaian nilai-nilai Islam. Hal ini di ungkapkan oleh wakasek kurikulum bapak E. Zaenal Muttaqin bahwa program tahunan yang telah dilaksanakan di SMK Plus Multazam yaitu memperingati tahun baru Islam pada tanggal 1 
Muharram $1440 \mathrm{H}$. dengan mengadakan pengajian dan lomba tumpeng, peringatan Maulid Nabi diisi dengan membaca shalawat bersama (al-Barjanji), peringatan Isra' Mi'raj dengan mengadakan pengajian tentang hikmah isra' mi'raj. Pada hari raya idul fitri mengadakan halal bihalal dengan semua keluarga besar yayasan dan pada hari raya idul adha melaksanakan pemotongan hewan qurban. Pada bulan Ramadhan sekolah mengadakan kegiatan pesantren kilat untuk mengisi hari-hari puasa supaya bertambah nilai keimanan dan ketakwaan.

Adapun program intra kurikuler dalam strategi internalisasi nilai spiritual Islam di SMK Plus Multazam untuk membantu pembiasaan yakni dengan mata pelajaran muatan lokal tahfídz al-Qur'ân dan bahasa Arab. Hal ini merupakan program intra kurikuler yang menjadi pembeda dengan SMK lain di sekitarnya. Dengan penerapan pembelajaran muatan lokal berupa pelajaran tahfìdz al-Qur'ân dan bahasa Arab diharapkan dapat terintegrasi dengan citacita yayasan yang ingin memiliki santri hafidz dan hafidzah serta fasih berbahasa Arab. Adapun dalam pembelajaran tahfdizul Qur'an setiap siswa diharapkan mampu menghafal juz 30 dengan tambahan surat-surat mashur lainnya seperti surat yasin, ar-rohman, al-waqiah, al mulk, luqman, as-sajdah serta 20 ayat dari surat al-kahfi dalam kurun masa belajar tiga tahun. Sedangkan dalam pembelajan bahasa Arab diharapkan siswa mampu menguasai dasar-dasar ilmu nahwu sebagai landasan pembelajaran dan pengaplikasian bahasa dalam berpidato bahasa Arab di kegiatan ekstra kurikuler muhadharah.

Dengan kegiatan pembiasaan, baik yang harian, bulanan bahkan tahunan yang diterapkan di SMK Plus Multazam diharapkan siswa dapat terbiasa melakukan ibadah-ibadah baik yang mahdhah maupun ghair mahdhah. Selain itu, melalui pembiasaan ini juga dapat mendidik para siswa maupun guru untuk ikhlas karena Allah dalam beramal hingga tidak perlu lagi adanya paksaan dari sekolah.

Selain melalui pembiasaan, internalisasi nilai-nilai spiritual Islam di sekolah bisa ditumbuhkan dengan adanya hukuman bagi siswa yang melanggar atau menyimpang. Hukuman yang diberlakukan melalui kesepakatan siswa beserta guru baik wali kelas, BP/BK dan guru PAI serta PKN. Misalnya ada siswa yang merokok, bolos dari sekolah, tidak melaksanakan shalat berjama'ah dzuhur, telat masuk sekolah dan sebagainya. Hukuman yang diberikan kepada siswa yang melanggar atau amoral berupa hukuman yang menjerakan dan mendidik.

Dari penerapan nilai spiritual Islam di atas menegaskan bahwasannya tidak ada sanksi atau hukuman tertulis untuk tindakan amoral siswa terhadap pengamalan nilai spiritual. Namun dengan nasihat yang baik dan hukuman 
yang menjerakan supaya siswa bisa memperbaiki akhlaknya. Mengenai hukuman ini pula Allah telah memberikan contohnya dalam Alquran serta hadits dari Rasulullah terhadap orang-orang yang inkar atau menyimpang dari ajaran-Nya. Adapun hukuman bagi umat nabi muhammad ada yang di segerakan ada juga yang di tunggukan kecuali jika di taubati itulah yang di adopsi oleh SMK Plus Multazam melalui metode hukuman dalam menginternalisasikan nilai-nilai spiritual terhadap siswa dan guru.

Keteladan seorang guru merupakan aspek penting untuk membimbing siswa dalam penerapan nilai-nilai spiritual Islam. Secara tidak langsung apa yang dilakukan guru menjadi cerminan siswa dalam bersikap, mereka akan mengadakan penilaian secara langsung baik didalam kelas maupun diluar kelas.

Sudah semestinya seorang guru menjadi contoh atau suri tauladan bagi peserta didiknya sebagaimana Rasulullah menjadi suri tauladan bagi umatnya. Karena terkadang menasihati atau mendidik dengan ucapan saja tidak cukup. Nilai-nilai kecintaan terhadap sifat Rasul serta perintah Allah untuk memberi contoh yang baik melalui amal shaleh mesti menjadi landasan seorang guru dalam mendidik siswanya. Hal demikian yang dilakukan oleh guru-guru di SMK Plus Multazam yang menjadi pembina di setiap kegiatan keagamaan sebagai contoh taulan yang baik bagi peserta didiknya.

Nasehat sebagai upaya memberikan masukan yang baik sebagai bahan pertimbangan bagi siswa untuk menumbuh kembagkan penanaman nilai-nilai spiritual, baik amaliyah berupa penanaman akhlak yang mulia maupun peningkatan pemahaman nilai ketauhidan. Seorang guru memiliki kewajiban untuk memberikan nasihat yang baik yang dikaitkan dengan fenomena dalam kehidupan sehari-hari.

Di SMK Plus Multazam para guru memberikan nasihat kepada siswa baik ketika dikelas maupun diluar kelas. Penyampaian nasihat juga disampaikan ketika pelaksanaan upacara, kultum sebelum shalat berjama'ah maupun ketika mendapati siswa yang amoral atau melanggar tata tertib sekolah. Hal ini sangat di anjurkan apalagi bagi seorang guru yang memiliki wewenang kedua setelah orang tuanya di rumah. Dengan demikian adanya nasihat terhadap siswa bahkan antar sesama guru. Kesadaran dari dalam diri siswa juga merupakan aspek yang sangat penting untuk dapat menginternalisasikan nilai-nilai spiritual dalam kehidupan. Dari kesadaran tersebut siswa dapat mengetahui dengan sendirinya jika memiliki nilai spiritual yang tinggi.

Ketika peneliti bertanya kepada Ovi Siti Ropi'ah selaku siswi kelas 12 TKJ, penting mana antara nilai tinggi tetapi akhlaknya kurang baik dibanding dengan siswa yang nilainya biasa-biasa akan tetapi memiliki akhlak yang baik karena dapat menginternalisasikan nilai-nilai yang ada. Ovi menjawabnya 
dengan lebih memilih akhlak nya yang bagus daripada nilai. Karena, untuk mendapatkan nilai yang maksimal dapat dicapai dengan giat belajar kembali, tetapi jika akhlaknya yang kurang maka tidak ada kesadaran untuk menerapkan nilai-nilai spiritual yang ada dalam kehidupannya justru hal tersebut yang dapat lebih bahaya.

Melalui strategi nasihat, ilmu yang disampaikan oleh guru SMK Plus Multazam diharapkan siswa dapat mencerna lebih baik lagi mengenai kegiatan dan akhlaknya. Sebagaimana menyampaikan suatu kebaikan telah menjadi sifat Rasulullah SAW supaya tercipta akhlakul kariman serta tujuan yang diharapkan. Dengan demikian, dari rangkaian kegiatan program-program spiritual yang telah dilaksanakan tercerminlah nilai-nilai spiritual Islam yang melibatkan amalan syari'at agama Islam di SMK Plus Multazam.

Agar pekerjaan berjalan sesuai dengan visi, misi, aturan dan program kerja maka dibutuhkan pengontrolan dan evaluasi kegiatan, baik dalam bentuk supervisi, pengawasan, inspeksi hingga audit. Dalam pengontrolan kegiatan internalisasi nilai spiritual di SMK Plus Multazam, peneliti mengadakan observasi dokumentasi kegiatan serta prilaku siswa sehingga mendapatkan data seperti pada tabel berikut :

Tabel 1. Evaluasi Kegiatan Internalisasi Nilai Spiritual Islam di SMK Plus Multazam

\begin{tabular}{|c|c|c|c|c|}
\hline No & Strategi & Nama Kegiatan & Nilai Spiritual & Keterangan \\
\hline \multirow[t]{5}{*}{1} & Pembiasaan & $\begin{array}{l}\text { Shalawat \& tadarus } \\
\text { Alquran pagi, shalat } \\
\text { duha. }\end{array}$ & $\begin{array}{l}\text { Menumbuhkan rasa } \\
\text { cinta terhadap rasul, } \\
\text { cinta kepada Alquran, } \\
\text { tanda keimanan kepada } \\
\text { Allah dan sebagai rasa } \\
\text { syukur. }\end{array}$ & Tercapai \\
\hline & & $\begin{array}{l}\text { Shalat dzuhur } \\
\text { berjama'ah dan } \\
\text { pembacaan qur'an } \\
\text { surat al-waqi'ah. }\end{array}$ & $\begin{array}{l}\text { Ukhuwah/persaudaraan, } \\
\text { kedisiplinan, persamaan } \\
\text { derajat, ketauhidan, dan } \\
\text { syukur. }\end{array}$ & Tercapai \\
\hline & & $\begin{array}{l}\text { Hadoroh, yasinan } \\
\text { dan infak sedekah. }\end{array}$ & $\begin{array}{l}\text { Saling mendo'akan, } \\
\text { berbagi pada sesama, } \\
\text { dan bersyukur. }\end{array}$ & Tercapai \\
\hline & & $\begin{array}{l}\text { Ekstra muhadharah } \\
\text { dan pembacan al- } \\
\text { Barjanji. }\end{array}$ & $\begin{array}{l}\text { Rajin belajar, mandiri, } \\
\text { bertanggungjawab. }\end{array}$ & Tercapai \\
\hline & & Dzikir bersama. & $\begin{array}{l}\text { Mengingat Allah, } \\
\text { kebersamaan, syukur, } \\
\text { khauf, roja' }\end{array}$ & Tercapai \\
\hline
\end{tabular}




\begin{tabular}{|c|c|c|c|c|}
\hline & & Puasa Sunnah & $\begin{array}{l}\text { Kejujuran, ihsan dan } \\
\text { tawakal. }\end{array}$ & Tercapai \\
\hline & & $\begin{array}{l}\text { Perayaan hari besar } \\
\text { Islam (PHBI) }\end{array}$ & $\begin{array}{l}\text { Cinta pada Allah dan } \\
\text { Rasul, syi'ar Islam. }\end{array}$ & Tercapai \\
\hline 2 & Hukuman & $\begin{array}{l}\text { Semua kegiatan } \\
\text { serta tingkah laku } \\
\text { siswa }\end{array}$ & $\begin{array}{l}\text { Khauf, takwa, disiplin, } \\
\text { tanggungjawab. }\end{array}$ & Tercapai \\
\hline 3 & Keteladanan & $\begin{array}{l}\text { Semua kegiatan } \\
\text { serta tingkah laku } \\
\text { siswa }\end{array}$ & $\begin{array}{l}\text { Meneladani Rasul, } \\
\text { akhlakul karimah, } \\
\text { tablig. }\end{array}$ & Tercapai \\
\hline 4 & Nasihat & $\begin{array}{l}\text { Semua kegiatan } \\
\text { serta tingkah laku } \\
\text { siswa }\end{array}$ & $\begin{array}{l}\text { Saling menasihati, amar } \\
\text { ma'ruf nahyil munkar, } \\
\text { dan saling menyayangi } \\
\text { sesame. }\end{array}$ & Tercapai \\
\hline
\end{tabular}

Berdasarkan tabel di atas, peneliti menilai tingkat ketercapaian dari kegiatan internalisasi nilai spiritual di SMK Plus Multazam sudah tercapai walaupun masih banyak yang mesti ditingkatkan terhadap pengawasan dan evaluasi.

Menurut bapak Fuad Yusuf selaku kepala sekolah SMK Plus Multazam "memang kegiatan belum sempurna barjalan dengan baik, akan tetapi kami selalu berusaha yang terbaik dan optimis bisa lebih baik". Evaluasi kegiatan sekolah secara keseluruhan termasuk kegiatan spiritual selalu dilaksanakan setiap bulan sekali pada tanggal 20. Dari evaluasi yang dilaksanakan baik dengan yayasan, guru dan staff tata usaha diharapkan ada perbaikan-perbaikan di masa yang akan datang karena setiap sesuatu butuh proses. Mengenai kendala-kendala yang ada di lapangan dimusyawarah dalam rapat guru supaya terorganisir dengan baik.

Pendukung dan Penghambat Internalisasi Nilai-Nilai Spiritual Islam di SMK Plus Multazam

Suatu kegiatan yang dijalankan pasti menemui kendala-kendala dalam melakukan aktivitas tersebut, begitu juga dalam berbagai kegiatan yang dilakukan di SMK Plus Multazam tidak semuanya berjalan lancar dan juga menuai kendala baik yang datang dari siswa maupun guru.

Dari hasil observasi dan wawancara peneliti terhadap para guru serta siswa di SMK Plus Multazam mendapati bahwa terdapat beberapa faktor yang mendukung ataupun menghambat proses kegiatan internalisasi nilai-nilai spiritual Islam baik faktor dari dalam maupun faktor dari luar. Ibu Ucu 
Syamsiah selaku guru PAI, menyampaikan bahwa faktor pendukung dari proses internalisasi nilai-nilai agama adalah dari seluruh dewan guru, siswa dan orang tua yang terlibat dan bekerjasama untuk menyukseskan kegiatan dan aturan yang telah ada (wawancara tanggal 27 Agustus 2018 pukul 10.15 WIB)

Begitupula dengan penuturan dari bapak E. Zaenal Muttaqin selaku kurikulum mengenai faktor pendukung dari internalisasi nilai spiritual Islam di SMK Plus Multazam yang memang berangkat dari sumber daya pendidiknya. Dengan mengoptimalkan guru-guru yang mampu di bidang keagamaan, semisal guru PAI, guru tahfidz, pembina keagamaan, atau dalam waktu-waktu tertentu ada dari pembina yayasan memberikan pembinaan spiritual langsung baik kepada guru maupun kepada siswa. Pembinaan dilaksanakan dalam acara semi resmi atau dalam acara PHBI dengan mengundang mubalig untuk menambah wawasan atau pemahaman dalam bidang spiritual (wawancara pada tanggal 21 Agustus 2018 pukul $13.00 \mathrm{WIB}$ )

Selain dari adanya sumber daya pendidik dan saling kerjasama antara pendidik, siswa dan orang tua, faktor-faktor lainnya telah dipaparkan di strategi internalisasi. Faktor pendukung internalisasi yakni adanya ibadah harian, ibadah bulanan, ibadah insidental serta pemantauan langsung dari pihak sekolah.

Mengenai faktor penghambat internalisasi nilai spiritual Islam di SMK Plus Multazam yang dipaparkan bapak E. Zaenal Muttaqin bahwa hal tersebut dikarenakan heterogennya siswa sehingga dianggap sulit, karena anak-anak yang biasa ikut dan patuh bisa terpengaruhi oleh anak yang kurang rajin atau kurang baik. Di sekolah bukan hanya kegiatan keagamaan saja, otomatis kegiatan spiritual juga dapat terganggu seperti oleh kegiatan olahraga, hal itu juga dapat menghambatan penerapan nilai spiritual. Selain itu ada sebagian guru yang berhalangan hadir dalam kegiatan pengamalan Islam di sekolah seperti ke ikut sertaan dalam shalat duha dan shalat berjama'ah dzuhur (wawancara pada tanggal 21 Agustus 2018 pukul 13.00 WIB).

Menurut ibu Ucu Syamsiah mengenai faktor lain yang mendukung proses internalisasi nilai-nilai spiritual Islam adalah dengan berdirinya pondok pesantren. Di sekitar sekolah berdiri pesantren salafiah Al-Husaeni dan pondok pesantren tahfidz Alquran Multazam bagi siswa yang ingin fokus menghafal Alquran sambil sekolah. Untuk faktor penghambatnya yakni adanya masyarakat dan orangtua yang kurang memperhatikan putra putrinya dalam hal pengamalan spiritual Islam ketika berada di rumah dan lingkungan tempat tinggalnya. Akan tetapi pihak sekolah selalu berkoordinasi dengan masyarakat setempat dan lingkungan siswa jika mendapati hal-hal yang kurang berkenan (wawancara pada tanggal 27 Agustus 2018 pukul 10.15 WIB). 
Dari paparan di atas ditegaskan bahwa proses internalisasi nilai-nilai spiritual Islam di SMK Plus Multazam mempunyai beberapa faktor pendukung dan penghambat, akan tetapi para guru selalu berusaha memperbaiki proses belajar dan pembinaan nilai-nilai spiritual supaya berjalan dengan baik. Walaupun faktor-faktor lainnya juga banyak mempengaruhi seperti fasilitas sekolah yang semakin meningkat, media informasi dan teknologi yang semakin berkembang, dan psikologi para siswa yang berbeda-beda dalam menerima suatu proses internalisasi nilai-nilai spiritual Islam di SMK Plus Multazam.

\section{Kesimpulan}

Berdasarkan hasil penelitian dan pembahasan yang telah dideskripsikan, maka penulis menarik kesimpulan yang disesuaikan dengan rumusan masalah yang telah ditentukan, diantaranya sebagai berikut: Pertama, konsep internalisasi nilai-nilai spiritual Islam di SMK Plus Multazam melalui: tahap transformasi nilai supaya siswa mampu mengetahui nilai-nilai spritual, tahap transaksi nilai menuntut siswa dapat menyampaikan ilmu kepada yang lain dan tahap transinternalisasi dimana diharapkan siswa dapat istiqomah dalam beramal. Kedua, strategi internalisasi nilai-nilai spiritual Islam di SMK Plus Multazam dilaksanakan melalui perencanaan yang tertuang dalam kurikulum sekolah, mata pelajaran muatan lokal, ekstra kurikuler, kalender pendidikan sekolah serta tata tertib sekolah. Strategi internalisasi ini di organisir oleh pembina yayasan dan segenap pendidik yang ada di sekolah. Adapun pelaksanaannya melalui strategi langsung dan tidak langsung, strategi langsung meliputi pembiasaan, hukuman, keteladanan dan kesadaran siswa akibat dari pembiasaan yang di internalisasikan. Evaluasi dari seluruh kegiatan strategi internalisasi dilakukan dengan pengawasan melalui daftar hadir dan evaluasi dalam musyawarah guru setiap bulan. Ketiga, faktor pendukung dalam membentukan nilai spritual Islam siswa diantaranya melalui ibadah harian, ibadah bulanan, ibadah insindental, pemantauan langsung dari pihak sekolah serta berdirinya pesantren di lingkungan sekolah. Sedangkan faktor penghambat diantaranya karena heterogennya siswa dan kegiatan lain yang menghambat seperti acara olahraga serta adanya guru yang berhalangan hadir dalam kegiatan.

\section{DAFTAR PUSTAKA}

Azizy, A. Q. (2003). Reformasi Bermazhab: Sebuah Ikhtiar Menuju Ijtihad Saintifik-Modern (Cet. II). Jakarta: Teraju. 
Buzan, T. (2003). The Power of Spiritual Intelligence: Sepuluh Cara Jadi Orang Sukses yang Cerdas Secara Spiritual. Jakarta: PT. Gramedia Pustaka Setia.

Depdikbud. (2000). Kamus Besar Bahasa Indonesia. Jakarta: Balai Pustaka.

Frimayanti, A. I. (2017). Implementasi Pendidikan Nilai dalam Pendidikan Islam. Al-Tadzkiyyah: Jurnal Pendidikan Islam, 8 (II), 227-247.

Jalaluddin. (2004). Psikologi Agama (Edisi Revisi). Jakarta: Raja Grafindo Persada.

Latif, A. (2007). Pendidikan Berbasis Nilai Kemasyarakatan. Bandung: Refika Aditama.

Muhaimin, A. M. (1996). Strategi Belajar Mengajar. Surabaya: Citra Media.

Noviandi, F. (2018). 2 SMK di Tangerang Tawuran, 1 Pelajar Tertancap Celurit di Kepala. Retrieved August 1, 2018, from https://www.suara.com/news/2018/08/01/020300/2-smk-di-tangerangtawuran-1-pelajar-tertancap-celurit-di-kepala

Nurhasanah, P., \& Supriyanto. (2012). Peran Guru dalam Pembinaan Perilaku Beragama pada Usia Remaja: Studi Kualitatif Naturalistik di SMA Muhammadiyah 09 Bekasi Timur. Turats, 8(1), 43-54.

Nursyamsu. (2017). Aqur`an Sebagai Sumber dan Ideologi Pendidikan Islam. Jurnal Al-Muta'aliyah STAI Darul Kamal, 1(1), 140-161.

Sugiyono. (2009). Metode Penelitian Kuantitatif, Kualitatif dan RఠD. Bandung: Alfabeta.

Zuriah, N. (2011). Pendidikan Moral dan Budi Pekerti dalam Perspektif Perubahan. Jakarta: Bumi Aksara. 